\title{
PORTER'S GENERIC STRATEGIES: AN EXPLORATORY STUDY OF THEIR USE IN JAPAN
}

\author{
Richard S. Allen \\ The University of Tennessee at Chattanooga \\ Chattanooga, TN \\ Marilyn M. Helms \\ Dalton State College \\ Dalton, GA \\ Margaret B. Takeda \\ California State University \\ San Bernardino, CA \\ Charles $S$. White \\ The University of Tennessee at Chattanooga \\ Chattanooga, TN
}

\begin{abstract}
While the use of Porter's generic strategies have been well documented in America and Europe, no studies have assessed their use in Japan. This research investigates if Japanese companies are indeed following Porter's generic strategies or continuing to follow more traditional "Japanese" management strategies. Using a survey to operationalize Porter's generic strategies, Japanese managers were questioned about their firm 's current strategic practices. A factor analysis revealed Japanese firms are following only two strategies that could be identified as those of Porter. A cost leadership strategy was the most frequently used strategy, and the differentiation strategy was used the least. There was no evidence of organizations using a focus strategy. Interestingly, two additional strategies emerged that did not fit Porter's research but are in line with traditional Japanese strategies including a supply chain focus and a training based strategy.
\end{abstract}

\section{Introduction}

Japan is experiencing a shrinking economy, failing stocks, rising unemployment, restructuring and job cuts. Without reforms, the economy is only predicted to grow $0.8 \%$ a year from 2006 to 2010 according to country advisors (Lorange $\&$ Turpin, 2004). Layoffs, such as 800 workers from Mitsubishi, have caused a change of attitude as many young people are abandoning hopes of landing life- 
time jobs (Wiseman, 2001). Bankruptcies are soaring and leaving behind a record level of debt in the country ("Japan Corporate Failures Up," 2001). A study team at Japan's Economy, Trade and Industry Ministry even called for improving disclosure rules for initial public offerings of venture firms to emphasize future business plans, rather than past performance ("Report Seeks to Improve," 2001).

In their groundbreaking and controversial article, "Fixing what Really Ails Japan," Porter and Takeuchi (1999) both of Harvard University, presented the cogent argument contending it was not government oversight of industry leading to the global success of Japanese companies, but rather operational effectiveness and strategy. They further blame the current long period of Japanese economic stagnation on the lack of discernable business strategies practiced by Japanese firms.

Based on these propositions of Porter and Takeuchi (1999), the study presented in this article explores the following important related questions:

- What types of discernable strategies are Japanese companies currently using?

- Do these strategies fit the Porter typology?

- What is the relative frequency of use of Japanese business strategies?

\section{Literature Review}

\section{Traditional Japanese Management Practices}

Traditional Japanese management is frequently cited as the cause of these problems. Historically, since WW II, all employees of a company share risks and gains of the operation. Even during economic crisis, layoffs are a last resort remedy. Lifetime employment, particularly for men in large companies, is the norm. Upper and lower management have similar responsibilities and product research is continuous as is the encouragement of new ideas and personal productivity.

Japan's industrial system is characterized by interdependent relationships among government, private, non-profit and community organizations. The keiretsu, or "lineage" system consists of a parent firm and trading company with the main bank as the institutional triumvirate guiding the activities of the entire keiretsu system. Each of these primary resource and power centers maintains close relationships with counterparts in the public sectors. The bank is guided by the Ministry of Finance (MOF); the trading company aligned with the Ministry of Economy, Trade and Industry (METI); and the parent firm guided by other government and non-private institutions (Ministry of Education or major universities). Companies such as National Telecom (NTT), for example, are closely tied with the Ministry of Posts and Telecommunications (MOPT). Other examples of these institutional relationships include the company labor unions and the Keidanren and Nikkeren (advisory councils) with both public and private sector participants (Okimoto \& Rohlen, 1988). These institutionalized practices are in place to help maintain informal ties between government and business.

The often cited reason for Japan's inability to react quickly to changes in market forces is the entrenched nature of group decision-making and the formalized sys- 
tems that seem to slow down even the most urgent of "causes" (Ishikawa, 1988). Japanese organizations practice nemawashi which is the process of preparing others through persuasion and sharing of information for a decision-making process. Nemawashi is a time consuming process which results in a fait accompli. Ringi (group decision-making through memos, meetings and formalized information and authorization gathering which results in a consensus decision) is another example of an institutionalized practice that results in long decision-making times and resistance to short-term change. Habatsu (informal and formal cliques of people which form in order to maintain information flows, control and power in stratified cross-sections of the organization) creates formal social structures resistant to ideas that threaten their autonomy. Kaizen or "continuous improvement" is yet another example of a way of life in Japanese companies that purposely inhibits "rash" action, or changes in the way things get done (Rohlen, 1974; Cole, 1989, Whitehill, 1991; Ishikawa, 1988, Porter \& Takeuchi, 1999).

\section{Limitations of Japanese Management and Strategic Challenge}

Japanese group decision making structures are driven by a sense of total commitment of group members to their leader and vice-versa (Ishikawa, 1988; Hamabata, 1990; Whitehill, 1991), this level of commitment has the potential to hinder the system's ability to identify and to react appropriately when the system is following a failing course-of-action. Japanese are reluctant to abandon such a system (Kahneman \& Tversky, 1979). Prospect theory suggests those "sunk cost effects" (Arkes \& Blumer, 1985) naturally occur once an investment in money, effort or time has been made, and individuals have a "personal stake" in the outcome, and choose not to alter their actions (Staw, 1976, 1981). When individuals become committed to a failing course-of-action, negative consequences will actually cause decision makers to increase their commitment of resources and undergo the risk of further negative consequences. This can evolve into a structurally supported behavior if an individual's group, organization or institution supports their behavior (Brockner \& Rubin, 1985; Ross \& Staw, 1986; Staw \& Ross, 1989; Whyte, 1993).

Today, the 15-year long "recession" in Japan has finally begun to take its toll on Japanese managers' faith in the Japanese "system." Recently, firms have begun to search for other ways to break out of their decades long commitment to the traditional Japanese management system and have discovered Michael Porter's $(1980,1985)$ generic strategies as a possible impetus for corporate change and renewal. According to Porter and Takeuchi (2000), the Japanese economy will emerge from more than a decade of recession only if Japanese firms become more competitive in the global marketplace.

Recently, the adoption of generic strategies has received much attention in public discussions in Japan. Japan's experience after the bubble economy with the chronic Asian financial crisis highlighted concerns as to whether Japan's once celebrated prosperity can be regained. The slow change and growth rate of new venture creation in Japan can be attributed to the conventional Japanese 
business culture, lifetime employment, the seniority system, labor unions inside companies, tight regulatory policies of the government, and the group-oriented risk adverse proclivity of the population. These cultural characteristics were developed from the past Asian agriculture system, a mono-national culture of an island country, and Confucianism.

\section{The Porter Prize for Japan}

Porter and Takeuchi (1999) argue it was precisely the governmental policies designed to macro manage industrial growth in Japan and globally which lead to the eventually downfall of the Japanese economy. Porter and Takeuchi point to examples of Honda, Sony, Nintendo and Sega as companies considered to be "mavericks" in Japan because they bucked government attempts at intervention. They consider these organizations to be the true Japanese success stories. The authors further argue these organizations rise to global dominance is explained by their well developed and defined corporate strategies, in addition to their operational excellence.

Since the publication of the article, and the subsequent book "Can Japan Compete?" (Porter \& Takeuchi, 2000), the Japanese Ministry of Economic Trade and Industry (METI, formerly MITI) established the "Porter Prize" to recognize Japanese companies achieving and maintaining superior profitability in their industry by implementing unique strategies based on innovations in products, processes, and ways of managing. The Porter Prize has the sole purpose of improving competitiveness of Japanese corporations. The evaluation criteria are originality, consistency, and high profitability of corporate strategies. The prize has been awarded to Japanese companies choosing to compete by delivering unique value based upon innovation and management. While the award is intended to motivate Japanese firms to develop clear, concise and manageable strategies, the degree to which the award is having an impact on strategic policy in Japanese companies as a whole has not been tested. To date, the Porter Prize recipients represent small to medium size firms in well defined niche markets. These companies do not represent the corporate base typically cited as creating the Japanese miracle, namely large keiretsu-based manufacturing conglomerates (Smothers, 1990).

The organizing body of the Porter Prize, the Graduate School of International Corporate Strategy at Hitotsubashi University, is the first "professional" graduate school established in Japan in April 2000 by the government with the single aim of improving competitiveness of Japanese firms in the global marketplace. This prestigious, well-funded program offers a full-time MBA program, taught entirely in English by many highly regarded American and European business professors.

By applying for the Porter Prize, it is hoped Japanese firms will become more attuned to the principles of competitive strategy. Through the application process, company managers are forced to consider important questions. For example, are we delivering a "unique value proposition" (a differentiated product or service targeted for a specific market niche)? Have we maintained strategic continuity 
over time? Have we innovated in ways that enable the strategy? Have we sustained superior profitability?

It is intended that, similar to its predecessor the Deming Award for Quality, the application process alone can serve as an impetus to rethink the current strategy or to pave the way for implementing distinctive strategy in the future. Benefits to the winners of the prize include recognition as a leader in strategy, increased public relations ability, and recruiting exposure. The winners are also featured in a case study series for Hitotsubashi Business Review (published by Toyo Keizai Inc.) and in other publications and strategic management textbooks (Hitt, Ireland \& Hoskisson, 2005).

Among the first Porter Prize winners were Matsui Securities and Mabuchi Motor as corporations in the single business category and Canon's Lens Division and two divisions of HOYA Vision Care as corporations in the multiple business category. Matsui Securities was highly regarded for the clear definition of "jobs-notto-do" in its business strategy. Established in 1931, this long-life securities firm ceased operations of its sales branches and telemarketing centers to specialize in online trading services. The firm has realized high rates of return on invested capital by focusing on the individual investors who have significant experience in stock exchanges (Asia Biz Tech, 2001).

\section{Porter's Generic Strategies}

While various types of organizational strategies have been identified over the years (Chrisman, Hofer \& Bolton, 1988; Porter, 1980), Porter's generic strategies remain the most commonly supported and identified in key strategic management textbooks (Dess, Lumpkin \& Taylor, 2004; David, 2003; Wheelen \& Hunger, 2004; Thompson \& Stickland, 2003) and in the literature (Miller \& Dess, 1993).

Porter (1980) proposed three generic strategies yielding competitive advantage, namely cost leadership, product differentiation, and focus. Porter (1980) suggests for long-term profitability, a firm must make a choice between one of the three generic strategies rather than end up being "stuck in the middle."

Cost Leadership. Lower costs and cost advantages result from process innovations, learning curve benefits, economies of scale, reductions, product designs that reduce manufacturing time and costs, and reengineering activities. A low-cost or cost leadership strategy is effectively implemented when the business designs, produces, and markets a comparable product more efficiently than its competitors. The firm may have access to raw materials or superior proprietary technology to lower costs.

Product Differentiation. Product differentiation fulfills a unique customer need by tailoring the product or the service, allowing organizations to charge a premium price to capture market share. The differentiation strategy is effectively implemented when the business provides unique or superior value to the customer through product quality, features, or after-sale support. The quality may be real or perceived based on fashion, brand name, or image. Firms following a differentiation strategy can charge a higher price for their products based on the product characteristics, 
the delivery system, the quality of service, or the distribution channels. The differentiation strategy appeals to a sophisticated or knowledgeable consumer who wants a unique, quality product and is willing to pay the higher price.

Focus. Focus, the third generic strategy, is based on adopting a narrow competitive scope within the industry. Focus strategies grow market share through operating in a niche market or markets not attractive to, or overlooked by, larger competitors. These niches arise from a number of factors including geography, buyer characteristics, product specifications, or requirements. A successful focus strategy (Porter, 1980) depends upon an industry segment large enough to have good growth potential but not of key importance to major competitors. Market penetration or market development can be an important focus strategy.

Porter (1985) also asserts focus can be based on (1) differentiation targeting a specific segment of the market with unique needs not met by others in the industry or (2) cost focused where the company has access to specialized production and operations equipment to save costs from smaller production lots or runs. Midsized and large firms use focus-based strategies only in conjunction with differentiation or cost leadership strategies. Focus strategies are most effective when consumers have distinct preferences or competitors overlook the niche (David, 2002).

\section{The Need for Japanese Strategy Research}

To date, no research has been conducted with a sample of Japanese organizations to determine to what extent they are following Porter's generic strategies. This may due in large part to the difficulty of outsiders gaining access to Japanese organizations, as well as the barrier of translating research instruments into a language and format suitable for Japanese respondents. Our research represents the first exploratory attempt to remedy this deficiency in our understanding of the current state of Japanese business strategies.

In summary, the Japanese government has been attempting to convince their firms to enact Porter based business strategies in an attempt to improve Japanese international competitiveness. There would appear to be strong forces for change in Japanese strategic planning practices. Considering the long-term Japanese recession, government backing of the Porter prize, and the role-model examples of successful Japanese businesses with better defined corporate strategies, one would presume that Japanese organizations should be primed for Porter-styled strategic planning.

Understanding the degree to which Japanese companies are embracing strategic management "Porter style" is essential to understanding the future of the Japanese economy. A significant shift in strategic policy is necessary for a successful transition from the traditional Japanese system to a more company-based, strategic thrust encouraged by Porter. The important issue is determining the current state of Japanese strategic planning. Has the emphasis on Porter begun to take root in Japan? Or is Japanese strategic planning still stuck in their traditional practices of the past? The main purpose of this study, therefore, is to assess what discernable 
business strategies Japanese companies are currently using, the relative frequency of use, and whether these strategies mirror Porter's generic strategies.

\section{The Research Question}

This study considers whether Japanese firms are enacting Porter's generic strategies. Organizational strategy, as noted earlier, can be grouped into key generic strategies. A priori, higher adherence to Porter's strategies is expected in Japanese firms, particularly given the government's emphasis on the Porter prize and desire to reverse the country's current economic position. Thus, the research question becomes: Are Porter's generic (1985) strategies being used in Japan and if so, what is their frequency of use in Japanese organizations?

\section{The Sample}

To test the research question, a sample of 101 managerial employees working in Japanese companies in Tokyo, Japan was surveyed. The subjects represented a broad cross-section of working adults. For inclusion in the final study, it was determined a respondent needed six months of employment at the organization under study to have adequate organizational knowledge to accurately complete the questionnaire.

Respondents had an average of eight years work experience. The time employed averaged 7.9 years (ranging from six months to 35 years) with a standard deviation of 8.6 years. Over $84 \%$ of the respondents were employed full-time. The sample included senior managers $(3.0 \%)$, middle managers $(16.2 \%)$, frontline managers $(7.1 \%)$, professional/technical $(21.2 \%)$, administrators $(4.0 \%)$, and others $22.8 \%$.

Twenty-two organizations with an average of 633 employees were included in the sample. (Note: Only $40.6 \%$ of the subjects reported their firm's name on the questionnaire. This information was presented as "optional" in order to increase the confidentiality and response rate of the survey.) Fifty-three percent were service organizations, $21 \%$ were manufacturing, and $27 \%$ were in the government, non-profit, other category. Fifty-six percent of the organizations were unionized (in Japan unions are "company unions" in which all employees belong to a union within the company).

\section{Methodology}

\section{Research Instrument}

In a previous study of American organizations, Allen and Helms (2002) developed and tested an appropriate scale based on Porter $(1980,1985)$ and Parker and Helms (1992) using a set of twenty-five questions regarding various strategic practices in order to operationalize Porter's generic strategies. This instrument was adapted for the Japanese survey. Respondents were asked to determine how frequently their organization uses the various strategic practices. Samples of the strategy survey questions are shown in Table 1. 
Table 1

Sample of Survey Questions

\begin{tabular}{|c|c|c|c|c|c|c|c|}
\hline & $\begin{array}{l}\text { Never } \\
(0 \%)\end{array}$ & $\begin{array}{l}\text { Almost } \\
\text { Never } \\
(1-20 \%)\end{array}$ & $\begin{array}{c}\text { Some } \\
\text { Times } \\
(21-40 \%)\end{array}$ & $\begin{array}{c}\text { About } \\
\text { Half } \\
(41-60 \%)\end{array}$ & $\begin{array}{c}\text { Most } \\
\text { Times } \\
(61-80 \%)\end{array}$ & $\begin{array}{c}\text { Almost } \\
\text { Always } \\
(81-99 \%)\end{array}$ & $\begin{array}{l}\text { Always } \\
(100 \%)\end{array}$ \\
\hline $\begin{array}{l}\text { Vigorous pursuit } \\
\text { of cost reductions }\end{array}$ & I & 2 & 3 & 4 & 5 & 6 & 7 \\
\hline $\begin{array}{l}\text { Providing outstanding } \\
\text { customer service }\end{array}$ & 1 & 2 & 3 & 4 & 5 & 6 & 7 \\
\hline $\begin{array}{l}\text { Improving } \\
\text { operational efficiency }\end{array}$ & 1 & 2 & 3 & 4 & 5 & 6 & 7 \\
\hline $\begin{array}{l}\text { Controlling the quality } \\
\text { of products/services }\end{array}$ & 1 & 2 & 3 & 4 & 5 & 6 & 7 \\
\hline $\begin{array}{l}\text { Intense supervision of } \\
\text { front-line personnel }\end{array}$ & 1 & 2 & 3 & 4 & 5 & 6 & 7 \\
\hline $\begin{array}{l}\text { Developing brand or } \\
\text { company name } \\
\text { identification }\end{array}$ & 1 & 2 & 3 & 4 & 5 & 6 & 7 \\
\hline $\begin{array}{l}\text { Targeting a specific } \\
\text { market niche or segment }\end{array}$ & at 1 & 2 & 3 & 4 & 5 & 6 & 7 \\
\hline $\begin{array}{l}\text { Providing specialty } \\
\text { products/services }\end{array}$ & 1 & 2 & 3 & 4 & 5 & 6 & 7 \\
\hline
\end{tabular}

The questionnaire included a cover page explaining the purpose of the survey and asked respondents to select a single organization to use as a point of reference in answering the survey questions. Respondents were guaranteed anonymity. If the organization under study had multiple divisions or subsidiaries, respondents were asked to base their answers on the specific division or subsidiary in which they worked. Respondents were given ample time to complete the survey and researchers were on hand to personally administer the questionnaire.

The questionnaire was translated and then pilot tested for clarity in language and meaning. Based upon the feedback from the pilot study minor adjustments were made to clarify meaning. The final Japanese version was then back translated into English to make sure no meaning was changed from the original English version.

\section{Analysis}

Responses to the 25 strategy items were subjected to a factor analysis to test whether the items naturally grouped into any of Porter's (1980, 1985) generic strategies. Using SPSS principal component analysis with a Varimax rotation and Kaiser normalization, a four-factor solution emerged explaining $58.8 \%$ of the variance. 
Items loading at 0.40 or greater were included in the resulting four factors. Three of the original 25 items did not load strongly onto a single factor and were excluded from further analysis, leaving 22 strategic practice items. The items and factor loadings for each factor are summarized in Table 2 .

The resulting four factors were then further interpreted for their meaning. Based on the items comprising the factors, two factors represent Porter generic strategies; namely, Cost Leadership and Product Differentiation. The Focus strategies were not represented. Two alternative strategies also emerged from the data. The first appears to represent the traditional Japanese Supply Chain management, while the second appears to represent a Training Based strategy.

In order to determine the frequency of use of the four strategies identified by the factor analysis, an additional procedure was performed. Each item in the questionnaire was rated on a Likert-type scale ranging from one through seven with a score of five or better indicating significant use of the strategy. (Thus respondents indicating "most times," "almost always," or "always," were included.) The scores on the respective questions loading on each of the four previously identified factors (cost leadership, product differentiation, supply chain management, and training) were then summed.

The resulting summated scale was used to assess which of the four strategies each respondent used. If a company scored above the cutoff score calculated by the product of the scale response (one through seven) times and the number of questions used to define the respective factor (for example, differentiation loaded on eleven questions), then the company was considered to be using the strategy. In a number of cases respondents reported the use of more than one major strategy which resulted in the percentages of strategy usage totaling to greater than $100 \%$. This conceptual overlap is to be expected because many of the strategic practices are not entirely exclusive to each respective strategy identified in the factor analysis. The results of this analysis are summarized in Table 3 .

\section{Discussion and Conclusions}

Based upon the factor analysis, four major strategies emerged from the data. Only two of Porter's generic strategies were apparent in the Japanese organizations. In the following discussion, the two Porter strategies in use in Japan, namely, Product Differentiation and Cost Leadership are outlined, while introducing the additional strategies which emerged from the data - the Supply Chain Strategy and the Training Strategy. 
Table 2

Factor Analysis of Japanese Strategies

\begin{tabular}{lccc}
\hline Strategy & $\begin{array}{c}\text { Product } \\
\text { Differentiation* }\end{array}$ & $\begin{array}{c}\text { Cost } \\
\text { Leadership* }\end{array}$ & $\begin{array}{c}\text { Supply } \\
\text { Chain }\end{array}$ \\
\hline
\end{tabular}

Innovation in Marketing Technology and Methods

.593

Developing Brand Identification

.407

Refining Existing Products/Services

.708

Developing a Broad Range of New Products/Services $\quad .659$

Forecasting New Market Growth

Forecasting Existing Market Growth

Extensive Training of Marketing Personnel

Building a Positive Reputation Within the Industry

for Technological Leadership

Building High Market Share

Providing Specialty Products/Services

Producing Products/Services for

High Price Market Segments

.608

* Corresponds to a Porter (1980) generic strategy

** New strategy observed in Japan 
Table 2 cont'd.

Factor Analysis of Japanese Strategies

\begin{tabular}{lccc}
\hline & $\begin{array}{c}\text { Product } \\
\text { Strategy }\end{array}$ & $\begin{array}{c}\text { Cost } \\
\text { Differentiation* }\end{array}$ & Leadership* $_{\text {Chain }}^{* *}$ \\
\hline
\end{tabular}

Controlling the Quality of Products/Services

.534

Providing Outstanding Customer Service

Improving Operational Efficiency

.769

Vigorous Pursuit of Cost Reductions

.732

Tight Control of Overhead Costs

.667

Partnering with Suppliers

Utilizing Advertising Strategy

Competitive Pricing

Intense Supervision of Front-Line Personnel

Extensive Training of Front-Line Personnel

* Corresponds to a Porter (1980) generic strategy

** New strategy observed in Japan 
Table 3

Frequency of Use of Strategies in Japan

\begin{tabular}{lc}
\hline Strategy & Percent of Companies Using Strategy $^{*}$ \\
\hline Cost Leadership & $41.4 \%$ \\
Supply chain & $36.2 \%$ \\
Training & $33.8 \%$ \\
Differentiation Strategy & $7.6 \%$ \\
\hline
\end{tabular}

* In a number of cases respondents reported the use of practices that represent more than one strategy which resulted in the percentages for the four strategies totaling greater than $100 \%$.

Again, please note that some firms reported using strategic practices that fit into multiple strategic factors. This is to be expected because few real world organizations implement pure strategies. Because of this the overall percentages do not add to $100 \%$. The factor analysis was not amenable to providing more factors to sub-divide the sample so that all subjects would report using practices that represent only a single factor. It would have been highly improbable for this to occur since many of the strategic practices overlap.

Cost Leadership Strategy. The most common strategy evidenced in Japanese organizations was Porter's Cost Leadership strategy. This strategy was being used in $41.4 \%$ of the organizations sampled. A cost minimization strategy stresses ongoing cost reductions and tight control of overhead costs to the exclusion of almost any other organizational or strategic issues. This is evidenced in the items of vigorous pursuit of cost reductions, tight control of overhead costs and improving operational efficiency.

The items comprising this factor clearly describe strategic practices which have been associated with the rise of Japanese products in the 1980s. For example, Japanese manufacturers were able to make great inroads internationally into such markets as consumer electronics, automobiles and steel. Their vigorous control of both costs and quality, along with outstanding customer service allowed Japan to export and compete globally in these markets.

In Japan, customer service is defined somewhat differently than in the West and this may explain its presence of this factor's make-up (Miyagawa \& Yoshida, 2005). Customer service results from a product's value as well as its on-time delivery. Customers often cite Japanese-made cars as offering better service due to the infrequent need for repairs. Thus good quality leads to low cost and the low cost leader (Schonberger, 1994), by providing a valued product, is in turn offering good customer service. Inversely, offering a poor quality product or a product at an inflated price would be seen as poor or even unethical customer 
service. It seems many Japanese companies are currently using one of Porter's generic strategies - cost leadership. But which of the other strategies were evidenced in the data?

Product Differentiation Strategy. This Porter strategy emerged in the factor analysis, but is being used much less frequently than any of the other strategies identified. In fact, a mere $7.6 \%$ of the organizations appeared to be utilizing this strategy. The failure of the Japanese banking system has been widely cited as the cause of the bursting of the Japanese economic bubble. But perhaps, as Porter contends, the relative lack of use of his generic strategies could be partially responsible for the inability of the Japanese economy to rebound.

When analyzing the items loading on this factor it is interesting to note most are marketing related. Since a product differentiation strategy emphasizes the uniqueness of a product or service and attempts to make the product or service special in the mind of the customer, one would expect marketing related activities to predominate. By fostering innovation as well as building a reputation of technological leadership a firm should be assured of a stream of new innovations to attract the interests of new customers as well as to meet existing customer's demands for uniqueness.

Part of Japan's recent economic malaise might be attributable the inability of Japanese companies to effectively differentiate their products from those of their competition. The entire country of Japan has operated under a strategic focus on steel, consumer electronics and automobile production since the end of WW II. Their core international markets for these products have been invaded by other nations over the past few decades. For example, American mini-mills as well as former Soviet bloc and other developing countries are now able to compete with Japanese steel, the Koreans and Chinese now compete in consumer electronics, and the Americans and Europeans have rebounded in their ability to compete in the automobile markets. Japan no longer enjoys a differentiated position in these markets. As such, very few organizations in the sample evidenced such a strategy. Perhaps Japan, an island nation dependent on exports, needs to regain a differentiated edge in some new markets if their economy is to rebound?

Focus Strategy. None of the emerging strategic factors appeared to represent a focus strategy. Practices typically associated with a focus strategy either did not clearly factor into a discernable strategy (i.e., "dropping unprofitable customers") or loaded onto the differentiation strategy (i.e., "providing specialty products or services" and "producing products/services for high price market segments"). Since Japanese firms are not utilizing Porter's focus strategies, this may be part of the reason for Japan's inability to rebound economically. Perhaps Japanese firms need to focus on specific product/service niches as well as develop new markets in which they can compete globally. This may be an important first step towards economic recovery.

In the literature on focus strategies, there is discussion of the focus strategy as one strategy or two. When discussed as two strategies - focus/low cost or focus/differentiation - the focus strategies are on a continuum with low cost at 
one end of the differentiation strategy and low-cost at the other end. It may be possible that some of the Japanese organizations that are in the Cost Leadership category are indeed practicing a focus-low cost type of strategy, but the data did not specify this.

Supply Chain Strategy. The first non-Porter strategy identified appears to be a traditional of Japanese Supply Chain strategy. This is not unexpected as the Japanese are well known for their passion of managing supply chains to optimize efficiency through such tactics as long-term supplier relationships, inventory minimization, and providing suppliers with predictable schedules of stable orders and regular demand (Liker \& Yu, 2000; Helper \& Sako, 1995). These high levels of Japanese supply chain collaboration have been created by deliberate policies to work with suppliers both individually and collectively in a circle of improvement and mutual benefit to increase cash flow and reduce operational costs of manufacturing (Nick \& Peter, 1997; Hines, 1994; Lamming, 1993; Womack \& Jones, 1996; Andersen Consulting, 1994; Smitka, 1991).

The results of the factor analysis indicated this strategic preference very clearly. Three items representing a supply chain approach, namely, partnering with suppliers, focus on advertising, and competitive pricing all loaded onto this factor at or greater than 0.7 . This strategy was the second most frequently used by $36.2 \%$ of the organizations.

The unique keiretsu or interlocking-directorate relationship of Japanese firms to their Japanese supplying organizations has led to a unique management linkage not typically seen and often illegal in other countries. This relationship has led to excellence in supply chain management. This tightly linked sharing of production and profit information among suppliers and manufacturers is easier in Japan due to their unique joint-ownership.

With the linked supplier joint-ownership relationship practice it is understandable partnering with suppliers would exist on this factor. Studies report Japanese automotive and high technology firms frequently engage in cost sharing with smaller suppliers (Asanuma \& Kikutani, 1992; Kawaskai \& McMillan, 1987). Others report the sharing of costs is brought about through investments in customizing assets and supplier support services and training (Dyer \& Ouchi, 1993; Chalos \& Sung, 1998; Kakabadse \& Kakabadse, 2000). Quinn and Hilmer (1994) found Japanese companies outsource primarily to improve the efficiency and quality of their own processes through focusing on a very few suppliers and building close interdependent relationships and supporting value-adding activities critical to quality.

The advertising strategy and competitive pricing can be partially explained by tight supply chain linkages (Asanuma \& Kikutani, 1992). Competitive pricing is only possible in a complex product if all suppliers understand the cost structure and use a version of target costing to set a consumer market price and work backwards from this price to reduce costs of production along the supply chain. Only with long-term and familial-like relationships is the greatest cost reduction possible and leadership in this area has long been attributed to Japanese 
management. Advertising too is part of the supply chain strategy not only for the marketing reasons of co-op advertising and cost sharing, but also backed up by a corresponding and correct production and operations strategy.

The American Production and Inventory Control Society (APICS) Dictionary (Blackstone \& Cox , 2004, p.1) defines sales-and-operations planning (SOP) as:

A process to develop tactical plans that provide management the ability to strategically direct its businesses to achieve competitive advantage, SOP integrates customer-focused marketing plans for new and existing products with the management of the supply chain. The process brings together all the plans for the business (sales, marketing, development, manufacturing, sourcing, and financial) into one integrated set of plans. The process must reconcile all supply, demand, and new-product plans at both the detail and aggregate levels and tie to the business plan.

Executed properly, the sales and operation planning process links the strategic plans for the business with its execution and reviews the performance measurements for continuous improvement. Thus for the effective utilization of an advertising strategy, production must be in line with the advertising in order to manufacture and distribute the goods to meet consumer's demands, and, more importantly, these consumer demands have been formed by advertising.

The Japanese are recognized for their passion of managing supply chains to optimize efficiency through such tactics as long-term supplier relationships, inventory minimization, and providing suppliers with predictable schedules of stable orders and regular demand (Liker \& Yu, 2000; Helper \& Sako, 1995). These high levels of Japanese supply chain collaboration have been created by deliberate policies to work with suppliers both individually and collectively in a circle of improvement and mutual benefit to increase cash flow and reduce operational costs of manufacturing (Nick \& Peter, 1997; Hines, 1994; Lamming, 1993; Womack \& Jones, 1996; Andersen Consulting, 1994; Smitka, 1991). Large percentages $(36.2 \%)$ of the organizations surveyed are still clinging to this traditional business strategy.

While the practices associated with this strategy did not fit a traditional Porter generic strategy, one could assert the supply chain strategy is an attempt to move toward an adoption of a focus-low cost strategy. The key tenets of supply chain collaboration are to reduce operational costs of logistics, distribution and production while minimizing raw materials, work-in-process and finished goods inventories. In a focused or niche environment, the supply chain strategy can work to lower costs below other competitors thus creating a market advantage.

Training Strategy. The other strategy operating in Japanese organizations was a training strategy. The items loading on this factor included: 1) extensive training of front-line personnel, 2) intense supervision of front-line personnel, and 3) extensive training of marketing personnel. This strategy was evidenced 
in $33.8 \%$ of the organizations surveyed; making it the third most frequently used strategy.

This is the second non-Porter strategy identified. Like the Supply Chain strategy, it too appears to be a traditional Japanese strategy. Japan is well known for intense, company-wide training as well as supervision of all employees in a rigid, hierarchical structure. Many researchers have attributed Japan's success to their unique style of management, structure, and training. Thus the supervision and training of front-line personnel and marketing personnel emerged as a separate strategic factor due to the rich history and adherence to "Japanese Management" within many of the companies operating in Japan. This training and management style worked so successfully during the $1980 \mathrm{~s}$ in the heyday of Japan's industrial success and companies follow this proven strategy today.

The key features of Japanese management are the seniority-based wage scale and promotion ladder, the traditional system of lifetime employment, and the concentration of power in middle management (Ghosn, 2003). Hull, Hage, and Zuumi (1985), in their study of the differences between the US and Japanese approaches to management, also revealed Japanese factories tend to invest relatively more in employee training, including more group processes such as the quality circle. They also found suggestions per employee were higher in Japanese factories. Clegg and Kono (2002), in their study of trends in Japanese management, offer a historical and cultural explanation for the intensive employee training. After WW II, skilled laborers were needed and Japan's lifetime employment encouraged such skill formation. Training costs were invested in secure personnel who would remain in the firm. The long-term employment fostered commitment and managers were free to invest funds into training employees with a view toward more long-term performance. With the decline of the concept of lifetime employment in Japan, this strategy may no longer be appropriate. An outsourcing type of strategy may be more competitive in today's international business climate.

Again while not a Porter generic strategy, it could be argued the training strategy is an attempt by Japanese managers to move toward the focus-differentiation strategy. The intense training results in either a standardized customer service and service delivery process for service firms or a quality manufacturing process with an attention to and elimination of process defects in a production environment. In either case - service or manufacturing - the result is a quality service or product. Quality products and services can command a premium price from customers and are thus perceived as a differentiated product, particularly in narrow market segments.

\section{Are Porter's Strategies Being Used in Japan?}

Given the four strategies, it appears Japanese businesses may be beginning to make a transition to Porter-based strategies, but the traditional Japanese business strategies remain. For example, the Japanese use Porter's Cost Leadership strategy the most (41.4\%), but the Product Differentiation strategy was infrequently used (7.6\%) and a clear Focus strategy did not emerge in the factor analysis. 
Clearly there is much room for improvement if Japanese organizations hope to achieve the ideals of the Porter Prize.

As shown in Table 2, the large percentage of Japanese firms following a cost leadership strategy can be easily explained as a natural reaction to the decade long economic slump and the necessity for cutting costs. Japanese labor is among the highest paid in the world, imports on raw materials remains high despite attempts to reform the system, and the Japanese are increasingly competing with Chinese and other Asian conglomerates for business that was once theirs exclusively. For these and other reasons, a cost leadership strategy is a means of survival.

Interestingly $70 \%$ of firms are still clinging to strategies linked to traditional Japanese management ( $36.2 \%$ for supply chain and $33.8 \%$ for training). This evidence further indicates a national strategic transition is incomplete. The traditional Japanese management strategies of training and supply chain management support Porter's (1996) assertion past Japanese success was based on operational effectiveness, the development of logistics to improve quality and cut costs, and on marginal product differentiation easily transferable to other companies. Even the high use of the Cost Leadership strategy lends further support to the notion the Japanese are stuck in the strategies of the past since cost control was vital to the previous success of Japanese industries in a global marketplace.

This exploratory study represents an attempt to identify current strategies in use in Japanese companies and the degree to which Japanese management is embracing the Porter Prize in Japan. While Porter asserts Japanese companies, "have no strategy" and this tradition will be hard to break, the fact that such a large scale effort is underway to "infect" Japanese companies with the "strategy bug" serves as a firm foundation for on-going inquiry and interest. While Japanese companies do indeed have discernable strategies, they do not fit neatly into Porter's typology. These strategies tend to be rooted in the past. It remains to be seen whether or not a transition to Porter's generic strategies alone is possible for Japan.

\section{Limitations and Areas for Future Research}

To date there have been no studies specifically designed to test whether Porter's strategies are in use by Japanese firms operating in Japan. This research used a convenience sample consisting of management employees from mostly large, institutionalized Japanese firms. Future research may be strengthened by using a sample comprised of a more diverse set of Japanese firms, including entrepreneurial firms, women-owned businesses, and even foreign firms operating in Japan. Another approach would be to conduct a longitudinal comparative study among firms competing for the Porter prize to identify specific practices and their relationship with strategies and performance and assess if their strategic practices mirror the questionnaire constructs for the generic strategies. The underlying assumption of the Porter prize is winning companies will be "successful". Since the current study does not address performance, future research should collect data on a longitudinal basis to aid in drawing causal inferences and validating the efficacy 
of Porter's strategies in use. Future studies should also investigate the relative effectiveness of these various strategies in Japanese firms. For example, which strategies are associated with higher levels of organizational performance?

From this research two unique strategies emerged from the Japanese management style and economic model, relevant only to Japanese companies operating in the country. Future research on strategies in Japan should examine the population of strategies being used. If global Japanese firms adapt strategy to their local environments, assessing the strategy of Japanese owned business operations operating outside Japan will help explain companies' global strategies.

As with any exploratory research, other important research questions have been uncovered. For example, what are the reasons Japanese firms are not adopting Porter's generic strategies? Are they too focused, too limiting to the traditionally open and fluid Japanese management system? Are Japanese companies too locked into quality improvement processes, lean manufacturing and productivity enhancements to shift toward more differentiation and other, more market driven strategies? Are the Japanese firms concentrating only on large markets and ignoring profitable niche markets and the corresponding focus strategies? Is the Japanese management tradition of evolutionary change and bottom-up consensus or team management antithetical to a top-down, rigid planning approach favored by Porter? All are areas for future research as in linking the particular strategies used to performance.

Finally the problems experienced in Japan need further research to determine the role of strategies or lack thereof in the current economic crisis. For example, what part of the problem is due to external and economic factors and what part is due to internal organizational strategies? Also when Japanese firms set up operations in the US, what strategic styles do they use and do they differ from the strategies used by the same organization in Japan.

This exploratory research is a first attempt to ascertain the current state of Japanese strategy. Future studies may use this as a baseline to see if the push towards Porter-based strategies in Japan is actually having an impact on Japanese business strategies. It will be interesting to see if this transaction is ever enacted and, if so, how long it will take.

\section{References}

Asia Biz Tech. (2001). Matsui Securities Co., Ltd. received the first Porter Prize award for its excellent corporate strategies. Tokyo: Nikkei News On-line.

Allen, R. S., \& Helms, M. M. (2002). Employee perceptions of the relationship between strategy, rewards and organizational performance. Journal of Business Strategies, 19(2), 115-139.

Andersen Consulting. (1994). The second world-wide lean enterprise benchmarking report. London: Andersen Consulting. 
Arkes, H. R., \& Blumer, C. (1985). The psychology of sunk cost. Organizational Behavior and Human Decision Processes, 35, 124-140.

Asanuma, B., \& Kikutani, T. (1992). Risk absorption in Japanese sub-contracting: A microeconomic study on the automobile industry. Joumal of Japanese and International Economics, 6(l), 1-9.

Blackstone, J. H., \& Cox, J. F. III. (2004). APICS Dictionary (Ith ed.). Alexandria, VA: APICS The Association for Operations Management.

Brockner, J., \& Rubin, J. Z. (1985). Entrapment in escalating conficts: A social psychological analysis. New York: Springer Verlag.

Chalos, P., \& Sung, J. (1998). Outsourcing decisions and managerial incentives. Decision Sciences, 29(4), $901-920$.

Chrisman, J., Hofer, C., \& Bolton, W. (1988). Toward a system for classifying business strategies. Academy of Management Review, 13,413-28.

Clegg, S., \& Kono, T. (2002). Trends in Japanese management: An overview of embedded continuities and disembedded discontinuities. Asia Pacific Journal of Management. $19(2-3), 269-278$.

Cole, R. (1989). Strategies for learning: Small group activities in American, Japanese, and Swedish Industry. Berkeley, CA: University of California Press.

David, F. (2002). Strategic management: Concepts (9th ed). Upper Saddle River, NJ: Prentice-Hall.

Dess, G. G., Lumpkin, G. T., \& Taylor, M. (2004). Strategic management: Text and cases. New York: McGraw-Hill Higher Education.

Dyer, J. F., \& Ouchi, W. G. (1993). Japanese-style partnership: Giving companies a competitive edge. Sloan Management Review, 35(1), $51-63$.

Ghosn, C. (2003). Japanese-style management and Nissan's revival. Japan Echo, 30(5), $15-18$.

Hamabata, M. M. (1990). Crested kimono: Power and love in the Japanese business family. Ithaca, NY: Cornell University Press.

Helper, S. R., \& Sako, M. (1995). Supplier relations in Japan and the United States: Are they converging? Sloan Management Review, 36(3), 77-84.

Hines, P. (1994). Creating world class suppliers: Unlocking mutnal competitive advantage. London: Pitman. 
Hitt, M. A., Ireland, R. D., \& Hoskisson, R. E. (2005). Strategic management-Competitiveness and globalization, concepts and cases (6th ed.). New York: South-Western Publishing.

Hull, F. M., Hage, J., \& Zuumi, K. (1985). R \& D management strategies: America versus Japan. IEEE Transactions on Engineering Management, 2, 78-84.

Ishikawa, H. (1988). Kaizen. New York: Penguin Books.

Jiji Press. (2001, November 14). Japan corporate failures up 11 percent in October. Jiji Press English News Service, 1-2. Tokyo.

Jiji Press. (2001, December 7). Report seeks to improve venture disclosure rules. Jiji Press English News Service, 5-6. Tokyo.

Kahneman, D. \& Tversky, A. (1979). Prospect theory: An analysis of decision-making under risk. Econometrica, 47, 263-291.

Kakabadse, N., \& Kakabadse, A. (2000). Critical review - Outsourcing: A paradigm shift. The Journal of Management Development, 19(8), 670-728.

Kawasaki, S., \& McMillan, J. (1987). The design on contracts: Evidence from Japanese subcontracting. Journal of Japanese and International Economics, I(3), 327-45.

Lamming, R. (1993). Beyond partnerships: Strategies for innovation and lean supply. Hemel Hempstead, England: Prentice-Hall.

Liker, J. K., \& Yu, Y. C. (2000). Japanese automakers, U.S. suppliers and supply-chain superiority. MIT Sloan Management Review, 42(1), 81-93.

Lorange, P., \& Turpin. D. (2004). How can Japan grow? MIT Sloan Management Review. 45(2), 96.

Miller, A., \& Dess, G. (1993). Assessing Porter's (1980) model in terms of its generalizability, accuracy, and simplicity. Journal of Management Studies, 30, 553-585.

Miyagawa, M., \& Yoshida, K. (2005). An empirical study of TQM practices in Japaneseowned manufacturers in China. The International Journal of Quality \& Reliability Management, 22(6), 536-554.

Nick, R., \& Peter, H. (1997). Supply-chain management and time-based competition: The role of the supplier association. International Journal of Physical Distribution and Logistics Management, 27(3-4), 210-225.

Okimoto, D., \& Rohlen, T. (Eds.). (1988). Inside the Japanese system: Readings on contemporary society and political economy. Los Angeles: Stanford University Press. 
Parker, B., \& Helms, M. M. (1992). Generic strategies and firm performance in a declining industry. Management International Review: 32(1). 23-29.

Pearce, J. A. II, \& Robinson, R. B., Jr. (2003). Strategic management: Formulation, implementation and control of competitive strategy (8th ed.). New York: McGraw-Hill Higher Education.

Porter, M. E. (1980). Competitive strategy. New York: Free Press.

Porter, M. E. (1985). Competitive advantage: Creating and sustaining superior performance. New York: Free Press.

Porter, M. E., \& Takeuchi, H. (1999). Fixing what really ails Japan. Foreign affairs, 6681.

Porter, M. E., \& Takeuchi, H. (2000). Can Japan compete? Boston: Harvard Business School Press.

Quinn, J. B., \& Hilmer, F. G. (1994). Strategic outsourcing. Sloan Management Review. $35(4), 43-55$.

Rohlen, T. (1974). For harmony and strength: Japanese white collar organization in anthropological perspective. Berkeley, CA: University of California Press.

Ross, J., \& Staw, B. (1986). Expo 86: An escalation prototype. Administrative Science Quarterly: 31, 274-297.

Schonberger, R. (1994). Human resource management lessons from a decade of total quality management and reengineering. California Management Review, 36(4), 109-134.

Smitka, M. (1991). Competitive ties: Subcontracting in the Japanese automotive industry. New York: Columbia University Press.

Smothers, N. P. (1990). Patterns of Japanese strategy: Strategic combinations of strategies. Strategic Management Journal, 1/(7), 521-534.

Staw, B. M. (1981). The escalation of commitment to a course of action. Academy of Management Review; 6, 577-587.

Staw, B. M. (1976). Knee-deep in the big muddy: A study of escalating commitment to a chosen course of action. Organizational Behavior and Human Performance, 16, $27-44$.

Staw, B. M., \& Ross, J. (1989). Understanding behavior in escalating situations. Science, $246,216-220$.

Thompson, A., \& Strickland, A. (2003). Strategic management: Concepts and cases (13th ed.). New York: McGraw-Hill Higher Education. 
Whitehill, A. M. (1991). Japanese management: Tradition and transition. London: Routledge Press.

Wiseman, P. (2001, September 10). Japan enters "danger zone." USA Today, p. 3B.

Wheelen, T., \& Hunger, J. D. (2004). Strategic management and business policy (9th ed.). New York: Prentice Hall.

Whyte, G. (1993). Escalating commitment in individual and group decision-making: A prospect theory approach. Organizational Behavior and Human Decision Processes, $54,430-455$.

Womac, J., \& Jones, D. (1996). Lean Thinking. New York: Simon and Schuster.

Richard Allen is the UC Foundation Associate Professor of Management at the University of Tennessee at Chattanooga. He received his Ph.D. in Strategy, Environment and Organizational Studies from the University of Pittsburgh. His research interests include organizational development and the strategic use of rewards. Prior to entering academia, he spent over 15 years in a variety of corporate management, training and consulting roles.

Marilyn Helms is the Sesquicentennial Endowed Chair and professor of management at Dalton State College. She earned her doctorate of business administration degree from the University of Memphis. Prior to joining DSC, she was the George Lester Nation Professor of Management at UT-Chattanooga. She was a Fulbright teaching and research award to Coimbra, Portugal. Her research interests include manufacturing strategy, quality, and international management.

Margaret Takeda is an adjunct professor at California State University, San Bernanrdino. She earned her Ph.D. in International Business/Human Resource Management from the University of Pittsburgh. Prior to joining the CSU faculty, she was an associate professor of management at The University of Tennessee at Chattanooga, and associate professor of international business at Aoyama Gakuin University, Tokyo, Japan. Her research interests include international human resource management, international business, spirituality and leadership, and Japanese management.

Charles S. White holds the UC Foundation and Hart Professorships in Management at the University of Tennessee at Chattanooga. He received his Ph.D. in management from Arizona State University in 1981. Dr. White teaches in the areas of general management, organizational behavior, small business, and research methods. 